\title{
Kurbağa Prens Özelinde Dijitalleşen Masallarda Hegemonik Erkekliğin Yıkımı
}

\author{
Özlem Agvan (i), İstanbul
}

doi) https://doi.org/10.37583/diyalog. 1030305

\begin{abstract}
$\ddot{\partial} z$
"Bir varmış, bir yokmuş" tekerlemesiyle başlayıp, okurunu Pertev Naili Boratav'ın deyimiyle "kendi içindeki bir mantı̆̆ $l$ " üzerinden "peşin olarak kabul edilmiş imkânlar" dünyasına alan masallar, dijitalleşen günümüz dünyasına kadar 200 yıldan fazla tarihsel arka planıyla barındırdığı imgesel evreni bugün dijitale taşımış yazınsal bir türdür. Mekân-sızlık- ve zaman-sızlık- bağlamında kurmuş olduğu yapı gereği, dijitale dönüşümünde başka bir evren kurma imkanına yer bulan masallar, hegemonyanın kurmuş olduğu düzeni alt üst etme sancısını da doğurmuştur. Bu bağlamda Grimm Kardeşler'in yazmış olduğu geleneksel Kurbağa Prens (1812) masalına eklediği pek çok prenses protagonistiyle, yeni bir dil inşa eden Fadime Uslu tarafından yazılan Kurbağa Prens (2020) masalında hegemonik erkekliğin yıkımı mevcuttur. Geleneksel masallarda dışa vurulan arzu alanını, yapısökümcü irdelemeyle elen alan ve bunu dijital platforma da taşıyan anti-masal Kurbağa Prens; geleneksel masallara karşı bir duruş olarak ortaya çıkan anti-masallardaki büyü bozuculuğunu ortaya koyma amacıyla bu makalenin odak masalı olmuştur. Makalede; Kurbağa Prens özelinde, toplumsal heteronormatif bir yapı inşa etme ve bunun temsillerini üretme mahali olarak masallar, R.W. Connell'in Gramsci'den çıkarak kavramsallaştırdığ "hegemonik erkeklik" söylem üzerinden ele alınmıştır. Dilin bilinçdışı gibi şekillenmesi üzerinden toplumsal cinsiyet nifak tohumlarının ekildiği geleneksel masalların erkeklik söylemine karşı; yeni söylemler üreten antimasallar, Kurbağa Prens modeli üzerinden incelenmiş ve sadece Disney'in çektiği filmler yoluyla değil bugün dizilerden reklamlara; oyunlardan şarkılara kadar pek çok kültürel alanda inşa etmiş olduğu ve temsilleriyle devamlılığını sağladığı kalıplaşmanın "başka bir dünya mümkün" diliyle yeniden yapılanmasına bakılmıştır.
\end{abstract}

Anahtar Sözcükler: Hegemonik Erkeklik, Kurbağa Prens, Masal, Toplumsal Cinsiyet.

\section{Abstract (English)}

\section{Challenging Hegemonic Masculinity In Digitalized Tales Specific To The Frog Prince}

Tales that start with the nursery rhyme "Once upon a time" and take the reader into the world of "preagreed possibilities" through a "logic within itself" as Pertev Naili Boratav puts is a literary genre that has transformed its imaginary universe to the digital with its historical background dates back more than 200 hundred years. Due to the structure having been established in the context of space-lessness and timelessness, the tales that have the opportunity to establish another universe in its digital transformation have also caused the pain of overturning the order established by hegemony. In this context, there is the destruction of hegemonic masculinity in the Frog Prince (2020) tale written by Fadime Uslu, who built a new language with many princess protagonists added to the traditional Frog Prince (1812) tale written by

Einsendedatum: 23.10.2021

Freigabe zur Veröffentlichung: 01.12.2021 
the Grimm Brothers. The anti-tale Frog Prince, which deals with the field of desire expressed in traditional fairy tales with deconstructive analysis and carries it to the digital platform; has been the focus of this article in order to reveal the disenchantment of anti-tales, which emerged as a stance against traditional tales. In the article and in the case of the Frog Prince, fairy tales as the site of constructing a social heteronormative structure and producing its representations, is discussed through the discourse of "hegemonic masculinity" that R.W. Connell conceptualized out of Gramsci. Against the masculinity discourse of traditional tales, in which the seeds of gender discord are planted through the unconscious shaping of language; anti-tales that produce new discourses have been examined through the Frog Prince model and not only through the films produced by Disney, but from TV series to commercials; the restructuring of the stereotype, which it has built and maintained in many cultural areas from plays to songs, has been analyzed with the language of "another world is possible".

Keywords: Hegemonic Masculinity, The Frog Prince, Fairy Tale, Gender. 


\section{EXTENDED ABSTRACT}

Tales, that start with the nursery rhyme "Once upon a time" and take the reader into the world of "pre-agreed possibilities" through a "logic within itself" as Pertev Naili Boratav puts, is a literary genre that has transformed its imaginary universe to the digital with its historical background dates back more than 200 hundred years. Due to the structure having been established in the context of space-lessness and time-lessness, the tales that have the opportunity to establish another universe in its digital transformation have also caused the pain of overturning the order established by hegemony. In this context, there is the destruction of hegemonic masculinity in the Frog Prince (2020) tale written by Fadime Uslu, who built a new language with many princess protagonists added to the traditional Frog Prince (1812) tale written by the Grimm Brothers. The anti-tale Frog Prince, which deals with the field of desire expressed in traditional fairy tales with deconstructive analysis and carries it to the digital platform; has been the focus of this article in order to reveal the disenchantment of anti-tales, which emerged as a stance against traditional tales. In the article; In the case of the Frog Prince, fairy tales as the site of constructing a social heteronormative structure and producing its representations, is discussed through the discourse of "hegemonic masculinity" that R.W. Connell conceptualized out of Gramsci. Against the masculinity discourse of traditional tales, in which the seeds of gender discord are planted through the unconscious shaping of language; anti-tales that produce new discourses have been examined through the Frog Prince model and not only through the films produced by Disney, but from TV series to commercials; the restructuring of the stereotype, which it has built and maintained in many cultural areas from plays to songs, has been analyzed with the language of "another world is possible".

Although many different critical comments have been added to Connell's discussion on masculinity, hegemonic masculinity, which has been put forward by Connell, shows the dominance of men over women, as well as the domination relationship that men have established among themselves. Along with this, it is also important in terms of seeing the changeability of this domination. As a result of the debates caused by this concept, it also leads to the name of seeing the hierarchy system between subordinated masculinity and hegemonic masculinity today.

In the traditional Frog Prince tale, which assigns certain norms to men with their prince or father prototypes and thus establishes hegemonic masculinity; a masculinity that is physically strong, has political or domestic authority, whose orders are obeyed, and that subordinates women and therefore other men according to its own authority, to its own discourse has been established. The tale describing the man, who was excluded and subjected to a speciesist approach when he was a frog, carries the message that his existence will be confirmed by taking this hegemonic masculinity mold. The tale builds this innate gender-based balance of power over the male and female prototypes it contains and legitimizes this system by ending the tale with a happy marriage.

In the tale of the Frog Prince written by Fadime Uslu, who opposes this tale, hegemonic masculinity construction is not encountered. The tale does not repeat the norms established through the discourse of biological difference imposed on women and men; besides, it builds a fiction that supports individual development, labor, solidarity, and pluralism. Anti-tales have written the possibility of establishing a different discourse as a result of masculinity studies, in which sex, and thus gender, concepts are transformed with the support of the libertarian field provided by digitalization. Therefore, especially to children, anti-tales offer the opportunity that there is a possibility for another world, while they are important tools towards the destruction of the masculine hegemony established by adults.

To produce fairy tales with the awareness which does not discriminate between the 
species or genders, highlight the gender roles, establish a value system based on beauty or ugliness, and the fact that creating a masculine system victimizing men, as well as women, is an important deconstructive action to overturn heteronormative patriarchy through its own measures; and this comparison, which reveals the necessity of supporting as well as multiplying these actions, makes the function of fairy tales visible again. 


\title{
Giriş
}

Batı temelli modern düşüncenin tahakküm ${ }^{1}$ sistemi kurabilme adına inşa ettiği cinsiyet kavramı, bugün cinsiyetin doğal bir yasa olarak dayatıldığı ifşasıyla birlikte sosyal bilimlerin tartıştı̆̆ kavramların başında gelir. Toplumsal cinsiyet ve cinsel kimlik açılımları üzerine yapılan son çalışmalar, modern batı düşüncesine ait Kartezyen ikircilik yapının bedeni farklılaştırmasının neticesinde cinsiyeti doğal yasa olarak tanımlamasını yeniden tartışmaya açar. İlgili çalışma alanının önemli isimlerinden Judith Butler Cinsiyet Belası'nda (1999), bu tartışmaların feminist öznenin bölünmesinden dahası öznenin tartışmaya açık birliğinden kaynaklı olduğu ifade eder:

\begin{abstract}
Cinsiyet ile toplumsal cinsiyet arasındaki ayrım ilk başlarda 'biyoloji kaderdir' ifadesine itiraz getirmek için kullanılmıştı, aynı zamanda da cinsiyet biyolojik anlamda ne denli geri çevrilemez görünürse görünsün toplumsal cinsiyetin kültürel olarak inşa edildiği, dolayısıyla ne cinsiyetin nedensel sonucu ne de onun kadar sabit bir şey olduğu savi için de kullanılmaktadır. Toplumsal cinsiyetin cinsiyete getirilen çoklu yorum olarak tanımlanmasına firsat veren bu ayrım nedeniyle öznenin birliği zaten tartışmaya açıkbir meseledir. (Butler 2016: 50)
\end{abstract}

Özneye bir ben'lik inşa etme adına kadını erkekten ayıran ve böylece ikili cinsiyeti biçimlendiren şeyin söylem olduğunu ortaya koyan Jacques Lacan'dan yola çıkıldığında; kadın boşlukla sınırlandırılmış eksik söylem içerisinde kendisine ait olmayan cinsel kimliği edinme adına maske giydiği hatırlanır. Böylece toplumsalın dayattığı söylem üzerinden kendine ait olmayan bir sahteliği takınan özne, doğuştan atanan bir cinsiyetin varlığ yasasını bu maske dolayımıyla sorgulamaz. Nitekim Cinselliğin Tarihi'nde (1979) Michel Foucault kültürel söylemin bedene, kültürel tutarlılık adına kurduğu dikotomi ${ }^{2}$ sistemine uygun bir şekilde belli bir cinsiyet taşıyıcısı olma zorundalığı dayattığını ifade eder. Bedeni disipline ve terbiye etme amacindaki Foucault'un biyoiktidar olarak tanımladığı denetim sistemi, bedeni biyolojik fark kurgusu üzerinden esasında güç ilişkilerini uygulama ve devam ettirme, başka bir ifade ile tahakküm ilişkilerini kurma ve meşrulaştırma alanı olarak işlevselleştirir. Bu bağlamda Foucault'un ifadesiyle nüfusun biyopolitiği olarak gördüğü bedeni, dolayısıyla da cinselliği, iktidarının mekanizmasını düzenleme alanı olarak işaretler. Bedeni, söylemin performatif ${ }^{3}$ alanı olarak işaretleyen bu mekanizma; tekrar yöntemiyle cinsiyet kalıplarını inşa eder ve böylece kurduğu tahakkümü meşrulaştırır. Bugünkü ilgili çalışmalar ise, cinsel farkın sadece kurulu biyolojik gerçeklikler üzerinden değil aynı zamanda bir söylem inşası sonucu oluştuğunu işaret eder ve cinsiyet-toplumsal cinsiyet kavramlarını Derrida'nın yapıbozumcu ya da Butler'ın ifadesiyle yerine yerleşmiş muhtevayı yerinden çıkarma yöntemiyle sorgular.

Erkek veya kadın olarak, kavramaya çalıştığımız nesnenin içinde yer alarak, eril düzenin tarihsel yapılarını algılama ve değerlendirmenin bilinçsiz şemaları biçiminde bünyemize katmış durumdayız; bu nedenle de, eril tahakkümü düşünürken, kendileri de tahakkümün ürünü olan düşünme biçimlerine başvurma riskini taşıyoruz. (Bourdieu 2018: 17)

\footnotetext{
${ }^{1}$ Bask1, zorlama.

2 Türkçeye ikileşim olarak çevrilen zıtlıklar üzerinden kurulan ikili yapı; erkek-kadın, kültür-doğa, üst-alt gibi.

3 Judith Butler'ın cinsiyet kavramını açıklarken bedenin işlevselleştirilmesi, normatifliğin eylemleme geçişini anlatma adına kullandığı kavram.
} 
Pierre Bourdieu'nun Eril Tahakküm (1998) eserinde geçen yukarıdaki ifadesiyle altını çizdiği, tahakküm işleyişini analiz ederken erilin dayattığı ikili cinsiyet sistemini istemeden de olsa - pekiştirme gibi bir riskin farkındalığındaki bu makale; anti-masal ya da karşı masal olarak adlandırılan gelenekselin ürettiği tahakküm sistemini görünür kılma ve yerinden etme gayretindeki masalları ele alır. Kurbağa Prens özelinde geleneksel masallarda yerine yerleşmiş olan R. W. Connell'in Gramsci'den yola çıkarak kavramsallaştırdığ 1 hegemonik erkeklik düzeninin dijitalleşen masallarda yerinden çıkarılmasını konu edinen bu çalışma, cinsiyet-toplumsal cinsiyet ve hegemonik erkeklik kavramlarına yönelttiği eleştirel bir bakış geliştirme amacı güder. Bu bağlamda makale; hegemonik erkekliğin yeniden üretimine cinsiyetsiz bir masal eleştirisi bakışıyla Jacob ve Wilhem Grimm kardeşler tarafindan yazına aktarılan geleneksel masal Kurbağa Prens örneğiyle Fadime Uslu tarafindan yeniden yazılan Kurbağa Prens anti-masal örneğini karşılaştırılmalı olarak ele alır.

\section{Kurbağa Prens(ler) ve Hegemonik Erkeklik Üzerine}

İktidar; kendi amaçları doğrultusunda hem temsiller üretme hem de kendi söylemini meşrulaştırma alanı olarak kurduğu araçları üzerinden toplumsal bir düşünme sistemi inşa eder. $\mathrm{Bu}$ düşünme sistemini inşa edebilme adına erekleştirdiği bedene de cinsiyetin toplumsaldaki temsili olma rolü biçilir. Sözlü ya da yazılı araçları üzerinden ikili cinsiyet sistemini kuran ve buna uygun temsilleri üreterek devamlılığını sağlayan hegemonya, öncelikle bunu biyolojik yasa olarak kurgular ve bu yasa üzerinden de kendi normlarını yani toplumsal cinsiyet rollerini belirler:

Toplumsal dünya, bedeni cinsiyetlendirilmiş bir gerçeklik ve cinsiyetlendirici görüş ve bölünme esaslarının taşıyıcısı olarak inşa eder. Algının bu bedenselleşmiş toplumsal programı, dünyadaki her şeye, en başta da bedenin kendisine, onun biyolojik gerçekliğine uygulanir. (Bourdieu 2018: 22)

Bourdieu burada toplumsalın inşa ettiği anatomik farklılığı, kurduğu cinsiyetlendirilmiş toplumsal rollerin nedeni olarak doğal gibi göstermesini ve bu sayede kendini meşrulaştırmasını işaret eder. Anatomik farklılık olarak bedene atanan cinsiyet, bu bağlamda hegemonyanın düzenini ve onun getirilerini gerekçelendirmiş olur. Esasında erkek ya da kadın bedenine ait olduğu ortaya atılan biyolojik farklar, erkekmerkezci bir cinsiyet kurgusudur ve bu anlamda erkeğe ya da kadına yüklenen roller de bu kurguyu destekler niteliktedir. Bourdie de erkekmerkezci sistemin kurduğu tahakküm ilişkisini tam da bu noktada kendisini meşrulaştırma alanı olarak inşa ettiğini dile getirerek, bu döngüsel nedenselliği “eril sosyodisenin özgün gücü” (Bourdieu 2018: 37) olarak yorumlar ve böylece: "bir tahakküm ilişkisini, kendisi de doğallaştırılmış bir toplumsal inşa olan biyolojik bir doğanın içine yerleştirerek meşrulaştır[dığını] ” (Bourdieu 2018: 37) vurgular. R.W. Connell'in ${ }^{4}$ kavramsallaştırdığı hegemonik erkeklik tanımı da bu eril

\footnotetext{
${ }^{4}$ Boğaziçi Üniversitesi Sosyal Bilimler Enstitüsü Türk Dili ve Edebiyatı Bölümü’nden yayınlanan Ahmet Duran Arslan'ın Hegemonic Masculinity in Murathan Mungan's Stories: Disclosure and Destruction başlıklı yüksek lisans çalışmasından alınan bir dipnot: "Araştırmalarının çoğunu sadece adının baş harfleriyle yayımlayarak herhangi bir toplumsal cinsiyet imâsından uzaklaşmaya çalışan Connell, dönüşümünü ileriki yaşlarında tamamlamış transeksüel bir kadındır. Eleştirel erkeklik çalışmaları
} 
tahakküm ilişkilerinin kurulumu amacında iki cinsiyete indirgenen bedene yüklenen rolleri kendi içinde tekrar ederek, erkekliği sadece fiziksele yüklemez. Cinsel ilişkideki işleyişi üzerinden belli fiziksel ve kültürel değerler yüklenen erkeklik, sırf bir penisle doğmasından dolayı değil toplumsal kurulumuyla gelişir. Günümüzün erkeklik araştırmaları, tektipleştirici erkeklik kavramına eleştirel bakar ve erkekliği biyolojik sebeplerle açıklamaktan uzak durmakla beraber onu sosyal ilişkilerin içerisinde şekillenen ve farklı biçimlerde ortaya çıkabilecek bir inşa olduğunu savunur. Erkekliği, toplumsallıkla bağdaştıran hegemonik erkeklik de tam olarak üstünlüğü elde etme yolundaki erkekliği tanımlar:

\begin{abstract}
Hegemonik erkeklik kavramında 'hegemonya' (terimin ödünç aldığı Gramsci'nin İtalya'daki sınıf ilişkileri analizlerinde söz konusu olduğu gibi) acımasız iktidar çekişmelerinin ötesine geçerek özel yaşamın ve kültürel süreçlerin örgütlenmesine sızan bir toplumsal güçler oyununda kazanılan toplumsal üstünlüktür. [...] Dinselöğreti veya pratiğe, kitle iletişim içeriğine, ücret yapılarına, ev tasarımına, yardım/ vergilendirme politikalarına vb. kök salan üstünlük hegemonyadır. (R.W.Connell 2000: 269)
\end{abstract}

Hegemonik erkeklik, erkek cinsine atanan genel rolden farklı olarak "kadınlarla ve tabi kılınmış erkekliklerle ilişkili olarak inşa edilir” (R.W.Connell 2000: 271). Nitekim hegemonik erkeklik; patriarkanın devamlılığı adına farklı erkeklik biçimleri inşa eder ve bu inşa üzerinden kadını ikincil konuma alır. Nitekim Connell'in hegemonik erkeklik tanımından yola çıkıldığında hegemonik erkeklik ile eril tahakküm arasındaki bağ dikkat çekicidir. Hegemonyanın kazanılması adına eril tahakkümünü kullanan ve böylece kurduğu hiyerarşi sisteminde kendini en üste alan hegemonik erkeklik; bu bağlamda sadece kadınları değil tüm öteki olarak konumladıklarını da ikincil konuma alır. Öyle ki Erkeklik: Imkânsız Íktidar adlı çalışmasında Serpil Sancar da bu konumu "Erkeklik, sürekli başka konumların 'ne olduğu' hakkında konuşma hakkını kendi elinde tutan ve bu sayede kendi bulunduğu konum sorgulama dışı kalan bir 'iktidar konumu'dur” (Sancar 2016: 16) ifadesiyle tanımlar. Bu bağlamda kadınların küresel anlamda erkeğe görelik üzerinden ele alınması, eril tahakkümün kadını -ve dolayısıyla bedeni- eril arzuya hizmet edecek şekilde işlevselleştirilmesini doğurur. Bilimsel gerçekler üzerinden cinsiyetin doğuştan atalı olduğu savını destekleyen kültürel yap1; cinsiyetin, kültürel olarak kurulmuş toplumsal cinsiyetten daha önceye ait olduğunu ve bu kategorileştirmenin doğal bir farklılık doğduğunu iddia eder. Bu farklılık üzerinden cinsiyete dayalı iş bölümü yapan sistem, erkek ve kadını farklı konumlara sabitler. Hegemonik erkekliği üreten sosyal kurumlarla -devlet, ordu, aile, yasa- desteklenen bu güç pozisyonu yanına aldığı heteronormative $\mathrm{e}^{5}$ ile kendini meşrulaştırır ve ilan eder. Bu ikili cinsiyet kurgusu sayesinde kendi tahakkümünü için heteronormatif bir güvence alanı yaratır ve tekrar yoluyla bunu korur. Bir diğer ifadeyle hegemonik erkeklik, ikili cinsiyet yapısı gereği erkek ve kadının girdiği kesişimsel ilişkide kurulan gündelik performatiflerle kurulur. Bu bağlamda tahakküm yapısından beslenen ve onu besleyen hegemonik erkeklik; erkeği, kurguladığ tahakkümcü erkek prototipine sıkıştırır. Cinsellik, sınıf, din, ırk, yaş, ten rengi, cinsel

alanında sıkça başvurulan bir kaynak olan Masculinities (Erkeklikler) adlı kitabını Robert Connell olarak imzalamış olan yazar, güncel çalışmalarını ise Raewyn Connell olarak imzalamaktadır.” (S. 5)

${ }^{5}$ Verili ikili cinsiyet düzen gereği, heteroseksüelliğin doğal ve toplumsal bir norm olduğu söylemidir Bireyin cinsiyetini ve bu cinsiyet üzerinden bireysel ve kültürel kabüller üreten yapı. 
yönelim gibi pek çok kültürel aracıyla bu prototipi belirler ve erkeğe -ve dolayısıyla da bunun üzerinden ikincil konumdaki kadına- belli kalıpları dikte eder. Hegemonik erkeklik sadece belli bir cinsiyete yönelik tahakkümden ziyade hem kadınlara hem de egemen gruba ait olmayan erkeklere yönelik bir hükmetme anlayışıdır. Bu bağlamda Bourdieu erkeğin, sistem içerisinde kurbanlaştırılmasını görünür kılar:

Kendilerini alçaltma ve yoksaymaya eğilimli bir toplumsallaşma uğraşına boyun eğdirilen kadınlar, feragat, teslim ve sessizlik gibi olumsuz erdemler öğrenirken, erkekler de mütehakkim temsilin mahkûmu, hatta sinsice kurbanıdırlar. (Bourdieu 2018: 67)

Eğitim, sünnet, askerlik gibi erkeklik ritüelleri üzerinden erkeği fiziksel ve kültürel normlara tabi tutan ve erkeğe eril şeref kavramını dayatarak potansiyel şiddetini meşrulaştırma alanı veren ataerkil; kadın gibi erkeği de kendi sisteminin devamlılı̆̆ adına işlevselleştirir. Yani iktidar ile cinsiyetlendirilmiş toplumsallıklar -eril ya da dişilarasındaki bağ; erkekliğin, tarihsel bir kültürün inşa ürünü olduğunu gösterir. Kısaca; hegemonik erkeklik, toplumda üstün olarak görülen patriarkal destekli erkekliktir. Bu bağlamda hegemonik erkekliğin yeniden üretilmesinde "Bir varmış bir yokmuş..." gibi hayali bir kurgudan bahsederken, masum görünen masalın rolünü ortaya koymak önemlidir.

Sözlü bir gelenek sonucu ortaya çıkan, toplumlara göre değiş̧enlik gösterdiği kadar insanlığın evrensel bir hazinesi olarak kabul gören masallar, toplumu etkilemesi ve toplumdan da etkilenmesi bağlamında ortak bir bilinçdışının ürünü olarak tanımlanabilir. $\mathrm{Bu}$ bağlamda masallar; bireysel olduğu kadar, toplumsal arzuların alanı olarak içerdiği iletilerin egemen anlayıştan uzak kalması beklenemez. Masalların bu fantastik metinlerden ibaret olmadığı, ele aldığı tema genişliği bağlamında paradoksal bir biçimde gerçeği yansıtan bir kültür ürünü olarak; yazarı/ söyleyeni belli olup olmamasından bağımsız bir biçimde, Hüseyin Köse'nin de ifadesiyle “kusurlu bir yaşamsal düzenin ütopik tasarımı, reel dünyada gerçek olay ve ilişkilerin biçimlenişe aracılık eden gizli bir telkin yöntemi olarak" (Köse 2015: 12) da yorumlanabilir. Başka bir ifadeyle, masal kurmaca yapısı gereği her ne kadar gerçekliğe mesafeli bir alanı teşkil ediyormuş gibi görünse de bir yandan da bilinçdışı arzuların yeri olarak gerçekliğe ayna tutucu kültürel bir ürünüdür. Masalın bu paradoksallığı üzerinden hegemonik düzen yeniden üretilir. Kaldı ki; bu yeniden üretim "değer yarglları inşa eder alttan alta, gizlice standart ölçüler koyar, birörnek yaşama, düşünme ve duyma biçimleri yaratır” (Köse 2015: 17), bu bağlamda hegemonik düzenin tekrar üreticisi ve devamlılık sağlayıcısı olarak masallar, kurmaca dili sayesinde bu yeniden üretimi doğrudan değil kapalı bir biçimde yapar. $\mathrm{Bu}$ kapalı formu sayesinde masum görünebilen bu eğlence aracının toplumsalın üretimindeki yerini analiz edebilme ve buna karşı bir duruş alabilme anlamında eleştirel bir bakışa tabi tutulmasının gerekliliğini M. Özlem Sezer Masallar ve Toplumsal Cinsiyet (2018) şöyle ifade eder:

Masalın ağır basan ideolojik yanına rağmen eleştirel okumadan yoksun kalması, onu toplumsal kodlarını işletmesi açısından özgür kılar. Genellikle hoşça vakit geçirme anlamıyla sınırlandırılır ve boş hayaller ya da yalanlar için kullanılan 'Bana masal anlatma!' söyleminde olduğu gibi masum bir tanımlamayla çocukça, bazen de niteliksiz bir sahtekârlık olarak nitelendirilir. Oysa masal, bilinçdışının simgeleriyle görünür yüzeyin altına girift labirentler kurarak, buradan tam da yalın amacına çıkmak üzere, 
olağanüstü kıvrak bir zekânın tüm maharetini gösterdiği ikincil bir hikâye işletir. (Sezer

2018: 16)

Bugün, toplumsal normları çocukluktan başlayarak dayatılmasında araçsallaştırılan masallara farklı bir söylem getirebilme amacıyla geleneksel masallar; özellikle feminist araştırmacılar tarafından, yapısöküme uğraması neticesinde anti- ya da karşı masallar ortaya çıkar. Klasik ya da geleneksel masalların süregelen kalıplarını sorgulamaya açmak, taşıdığı toplumsal(cinsiyet) normlarına uygun prototip üretme pratiğini değişime uğratmak, eril hegemonik söylem yerine başka bir kurguyla farklı bir söylem inşa etme pratiğini kurmak amacı taşıyan anti- ya da karşı masalların örnekleri günümüzde artmaya başlar.

Masalın kapalı formu üzerinden gizli mesaj iletme gücünü, toplumun uyutucusu ya da uyandırıcısı olarak kullanma imkânını gösteren yapısökümcü anti-masallar ya da karşı masallar; masalı iktidarın performans alanı olarak araçsallaştıran geleneksel masalların anlayışını ters-yüz ederek farklı bir kurgu ve bunun sonucunda farklı bir düşünce sistemi inşa edebilmeyi gösterir. Geleneksel masallara karşı muhalif bir duruşa sahip bu yeni masallar, geleneksel masalların işlevini değiştirme yolundadır. Nitekim masal; yer, zaman ve mekân belirsizliği üzerinden yazana ya da söyleyene sunmuş olduğu özgürlük alanında söyleyene ya da yazana kendi amacı doğrultusunda hikâyeyi şekillendirme fursatı sunar. Geleneksel masallar bu üç belirsizliği, egemenin belirlediği normlara bağlı kalarak kolektif arzu nesne ikameleri inşa etme adına kullanırken; antimasallar ise belirsizliğin vermiş olduğu güvenli alan firsatını eril hegemonyanın yıkımında kullanmıştır.

Rus yapısalcı kuramcılardan Vladimir Propp Rus halk masallarını incelediği Masalın Biçembilimi (1985) çalışmasında, masalların ele aldığı konular değişkenlik göstermesine rağmen, sabit ortak yapıları barındırdığını gösterir. Kuramcıya göre masaldaki kişilerin eylemleri bir işlevdir ve bu işlevler masalın temel kısımlarıdır. $\mathrm{Bu}$ nedenle masaldaki kahramanların isimleri, cisimleri değişse de esas olan eylemin işlevidir. Geleneksel masallar da bu değişmez yapıyı, ikili cinsiyet sistemi üzerinden verili normları devam ettirme adına kullanır ve protagonistlerine ${ }^{6}$ aynı işleve sahip eylemleri tekrar ettirmesiyle belli prototipler üretir. Bu protagonistlerin, doğuştan atanan cinsiyet kurgusu üzerinden hegemonyanın kurduğu dikotomik cinsiyet sistemden uzak durması beklenmez. Bu bağlamda masal, Butler'ın ifadesiyle cinsiyet denilen şeyin ta kendisi olan toplumsal cinsiyet kurgusunu yani hegemonyanın erkeği merkeze ve bu merkeze göre kadını ikincil konuma almasını tekrar eden prototipler üretir:

Toplumsal cinsiyet, verili bir cinsiyetin üzerine kültürün anlam işlemesi olarak anlaşılmamalıdır yalnızca (hukuki bir kavrayıştır bu). Toplumsal cinsiyet aynı zamanda, cinsiyetleri tesis eden üretim mekanizmasının ta kendisini belirtmelidir. Neticede toplumsal cinsiyetin kültürle olan ilişkisi neyse cinsiyetin de doğayla ilişkisinin o olduğu söylenemez. Toplumsal cinsiyet bir yandan da, 'cinsiyetli doğa'nın ya da 'doğal bir cinsiyet'in üretilmesinde ve bunların 'söylemsellik öncesi', kültür öncesi bir şeymiş gibi, siyasi olarak tarafsızken kültürün gelip üzerinde etki ettiği bir yüzeymiş gibi tesis edilmesinde kullanılan söylemsel kültürel araçtır. (Butler 2016: 52)

\footnotetext{
${ }^{6}$ Başkahraman, başkişi.
} 
Özellikle çocuklar için kurgulanmış olan masalların, toplumsal cinsiyet rollerinin belirlenmesinde ve devamlılığında oynadığı rol oldukça önemlidir. İktidarın doğuştan atadığı bu ikili cinsiyet sistemini sözlü ya da yazılı olarak devam ettiren geleneksel masallar, erkek ve kadın prototipler kurgular ve bu kurguları tekrarlayarak meşrulaştırır. $\mathrm{Bu}$ bağlamda da geleneksel masalların yapı bozuculuğundan bahsedilemez. Geleneksel masal; neticede erkek ve kadın protagonisti, egemen gücün altını oymaktansa, okuru/ dinleyeni edilgenleştirme amacında işlevselleştirir. Bir diğer ifadeyle masalın değişmez yapısını eril söylemin amacında kullanan geleneksel masal yapısökümcü değildir. Masallar ve Toplumsal Cinsiyet (2018) isimli çalışmasında Melek Özlem Sezer, geleneksel masalın idealist amaçlardan uzak durduğunu ve prototiplerin daha çok erkeklik üzerinden kurgulandığını yazar:

[...] klasik masalların kahramanlığı, idealist amaçlarla pek de ilgili değildir. Daha çok fiziksel gücün ve cesaretin gösterisi olarak erkeğin temel değerlilik ölçütüdür ve iki ana getiriye sahiptir: Ödül-kadın ve sosyal statünün yükselişi. (Sezer 2018: 21)

Başka bir ifadeyle, hegemonyanın toplumsal cinsiyet rollerini kurma araçlarından sadece biri olan geleneksel masal, cinsiyet kategorilerine uyan ya da uymayan protagonistler üzerinden çocuğu toplumsalın heteronormatif rollerine hazırlar. Toplumsalın belirlediği bu cinsiyet kategorilerine ve onun getirdiği kalıplara uyanlara ödül olarak heteroseksüel evliliği sunar. Geleneksel masal; evliliği bu noktada statü atlama, iktidarı elde etme, sınıf atlama, güzelliğe ulaşma gibi anlamlar yüklemesiyle erkeğe ve kadına bu ödüle ulaşması için girmesi gereken normları dikte eder. Erkek bu durumda fiziksel olarak güçlü, zengin, evin direği olmaya uygun, kahraman ruhlu imgelenirken; kadına ise naif, güçsüz, evine bağımlı, itaatkâr, masum, sadık bir imge verilir. Görülen odur ki hegemonya, sistemin devamlılığ masalların prototip kurma yöntemini aracı olarak kullanır. Nitekim toplumsalı üretme ve devam ettirme kaygısındaki geleneksel masal, kadını nesneleştirdiği kadar erkeğe de eril tahakküm uygulamaktan geri kalmamıştır.

İkili cinsiyet düzeni kuran toplumsal, beden üzerinden temsiller üretirken; masal da bu temsiller temelinde kendine prototipler oluşturur. Masal, hegemonyanın cinsiyetler arası bölünmesi yöntemiyle erili yükseltir ve toplumsal tahakkümü erkekmerkezci bir yerden inşa eder. Nitekim bu tahakkümü inşa etme ve meşrulaştırma alanı olarak hem erkek hem de kadın bedenini şekillendirme alanı olarak alımlar. Bourdieu'nün tanımıyla eril sosyodisenin özgün gücü, eril söylem üzerinden masalda kendini göstererek erkekmerkezci bir yöntemle bu anlamda bedeni biçimlendirir. Toplumsal ilişkilerin farklılaştırılmış beden üzerinden kurgulanması bir doğa yasası gibi sunularak cinsiyetçi bir iş bölümü/ eylem/ ritüel üretir. Mükemmel bir erillik kurma adına ürettiği eylemler, geleneksel masalların ikili cinsiyet sistemini meşrulaştıracak prototipler üzerindentekrar edilir. $\mathrm{Bu}$ bağlamda erkeği merkezine alan Kurbağa Prens geleneksel masalı da mükemmel erkek rolündeki erkek protagonisti prens statüsüyle hem fiziksel hem de toplumsal düzenin bir örneği olarak saygın bir yere alır ve hegemonik erkekliği yeniden inşa eder.

Altın topunu kuyuya düşüren prenses ile topu bulan kurbağanın sohbetiyle başlayan, Grimm Kardeşlerin yazına aktardığı geleneksel Kurbağa Prens masalı; ilk 
sahnede erkeğe kurtarıcı rolü verirken kadını çaresiz ve edilgen olarak gösterir. Kurbağanın sözlerini okuyucu direkt onun ağzından dinlerken, prenses ise düşüncelerini söze dökmez. Topunu kuyudan çıkarmasının karşılığında prensesten yemeğini ve yatağını paylaşmasını isteyen Kurbağa son olarak da ondan öpücük ister ${ }^{7}$. Böylece masal; geleneksel masalların evliliğe giden yolda dönüşümü başlatan eylem olarak işlevselleştirdiği öpüşme motifiyle tamamlanır. Nitekim Sezer de geleneksel masallarda şayet öpüşme bir dönüşüm etkisi yaratmıyorsa öpüşmenin motif olarak kullanılmadığını vurgular (Sezer 2018: 28). Masal, daha başındayken erkeğin isteğine direnen kadını biçimlendirme yolunda, evliliği kullanacağını açık eder.

Geleneksel masaldaki erkeğin fiziksel ve sembolik şiddeti olarak da okunabilecek olan öpüşme, tahakküm alanı olarak geleneksel masalın kadını edilgen konuma alışını da imgeler. Eril tahakküm düzeninin yeniden kurulmasında araç olarak kullanılan bu masal, hegemonyanın bakış açısıyla tahakküm altına aldığı kadını, cinsiyetçi kategorilerine uygun şekillendirir. Bu bağlamda kendini değersiz/ aşağı/ kusurlu gören kadın, otoritenin gücünü sorgulamaz ve onun tahakkümünü olumlar. Eril tahakküme onunkurduğu sistem gereği doğal (kurduğu cinsiyetçilik üzerinden bunu doğa yasası gibi sunması ve araçlarıyla bu yasayı sorgulanamaz kılışından dolayı sözde doğal) olarak boyun eğen kadın temsili üreten bu imgelem; kadını, eril hegemonya kurma ve meşruluğunu ilan etme alanı olarak işaretler. Hegemonik hiyerarşiyi yeniden üreten ve onu meşrulaştıran prens ve prenses arasındaki bu ilişki, eril hegemonyanın toplumsal kurgusunu tahakküm üzerinden cisimleşmiş örneği olur.

Kurbağa Prens geleneksel masalında eril hegemonik yapı, yalnızca prens-prenses arasındaki değil aynı zamanda baba-kız evlat arasındaki tahakküm ilişki üzerinden de eril söylemi için alan bulur. "Söz verdiğin şeyi yapmalısın," dedi. "Git, hemen aç kapıyı" (S. 278) diyen baba, kızına baskı yapar. Kurbağayı öpme konusunda direnen kızına, sözünü tutması yolunda otoritesini gösteren baba ve onun temsil ettiği otorite; kadına direnmemesini ve erkeğin söylemine sadık kalması yolunda prensesi bir prototip olarak kullanır ve sonunda prenses kurbağayı öper. Kadını maruz kalan tarafa alan bu öpüşme

\footnotetext{
${ }^{7}$ Masalın bazı versiyonlarında öpücük motifi kullanılmamıştır: “'Beni yukarı, odana çıkarıp yatağını hazırlar mısın, birlikte uyuyalım'. Bu sözleri duyan kralın kizı ağlamaya başladı çünkü soğuk derili kurbağadan korkuyor, ona dokunmaya eli varmiyordu. Oysa kurbağa onun güzelim, mis gibi yatağında yatmak istiyordu. Gel gelelim kizın gözyaşları babasını öfkelendirdi. Kral, 'Dertli zamanında sana yardım edeni şimdi hor görüyorsun ha!' dedi. Bunun üzerine kız kurbağayı iki parmağıyla tutup götürerek odasının bir köşsesine bıraktı. Ama yatağına yattığında kurbağa karyolaya sokularak, 'Öyle yorgunum ki, taş gibi uyuyacağım, 'dedi. 'Al beni yatağına, yoksa babana söylerim ha!'. Bu sözler üzerine küplere binen kralın kızı kurbağayı tuttuğu gibi var gücüyle duvara çarparak 'Artık susar mısın, çirkin kurbağa!' dedi. Ne var ki, kurbağa yere düştüğ̈̈ sirada değişime uğrayarak yaklşıkl, güzel gözlü bir prense dönüştü ve kisa bir süre sonra babasının da rizasıyla prensesin sevgili arkadaşı ve nişanlisı oldu" (Kardeşler 2017: 279280). Bu ve buna benzer versiyonlarda da öpüşme motifiyle verilen "çirkin olamazsın, kadının üstünde otorite kurabilen, istediğini yaptırmasını bilen, emreden, seçen, prens kadar toplumsalda kabul gören güce sahip, fiziksel olarak güçlü ve yakışıkl ol! Toplumsal normlara uyan bir kadın ödülün! Kurallara uy!” iletisini verdiği zorlayıcı, baskıcı, otoriter erkekliğin karşısına; susan, babasının sözünden korkan/ çıkmayan, pasif kadınlığa verilen "direnirsen kaybedersin, boyun ey, otoriteye uy ve güçlü erkek prototipine kavuş, böylece mutlu sona ulaş. Kurallara uy!" iletisinin tekrarını yatağına zorlama girme isteği gibi tacizci bir yerden görülür.
} 
sahnesi, onu erkeğin tahakküm alanına sokarken; erkek protagonisti bir kurbağa iken yakışıklı bir prense dönüştürür. Böylece Serpil Sancar'ın “Genç, kentli, beyaz, heteroseksüel, tam zamanlı bir iş sahibi, makul ölçütlerde dindar, spor dallarının birisini başarll olarak yapabilecek düzeyde aktif bedensel performansa sahip erkeklerin temsil ettiği erkeklik" (Sancar 2016: 30) olarak tanımladığı hegemonik erkeklik sınıfına alınan prens, ev içindeki hegemonik güç olan babanın da yardımıyla, kadın üzerinde tahakkümü kurar. Esasında bir kurbağa ile arkadaşlık kurma konusunda dahi endişeli olan prenses, prensin bu dönüşümüyle onunla evlenerek sonsuza kadar mutlu yaşar. Bu bağlamda; direnen kadın yerine boyun eğen -ki böylece de sistemin devamlılığına hizmet eden- bir kadın prototipi ile masal her ne kadar dış görünüş özellikleri önemli değil gibi bir ileti veriyormuş görünse de tekrar ettiği hegemonik erkeklik örneğiyle toplumsalı yeniden inşa eder ve onun devamlılığına hizmet eder.

Masalın yeniden ürettiği hegemonik erkeklik sadece kadın üzerinden değil, erkek protagonistler üzerinden de kurbanlaştırma mekanizmasını inşa eder. Erkeğe belli bir cinsiyet -dolayısıyla da toplumsal cinsiyet- rollerini dayatarak onu da eril tahakkümü için işlevselleştirir. Kurduğu biyolojik yasa gereği karşısına ödül/ hedef olarak yerleştirdiği kadın karşısında belli normlara sahip olmayı ya da olmamayı doğuran bu işlevselleştirme; erkeğe belli normların ya içinde olmayı ya da bu tabi olmayı dayatır. Bu bağlamda erkeği merkeze alarak kurduğu bu tebaiyet sisteminde, erkeğe her ne kadar çirkinliği yükleyebilir görünse de sonunda onu yine hak ettiği yere alır. Kurduğu eril türcü söylemiyle erkeğe güçsüz ve çirkin olduğunda bir kurbağa gibi değersiz olacağını böylece eril iktidarının hadıma uğrayacağını çünkü bir kurbağa olduğunda bir prensesin -pek tabi bir kadının- yatağına girme ödülünü kavuşamayacağı alt iletisini kurar. Öpüşme ya da yatağına girme, yani karşısındakinin rızasını almama pahasına istediğini yapabilme özgürlüğünü verdiği erkeğe; bu eril gücünü kadın üzerinde kullandığında istediği mutlu sona erişebilecektir dayatması ile erkeğin eril şeref kavramı üzerinden şiddetini meşrulaştırır. Prense dönüşen kurbağa üzerinden performansa dökülen bu erkek prototipi, hegemonik erkeklik kümesine dahil edilen tek erkek değildir. Ataerkinin önemli araçlarından biri olan evlilik kurumunun temsilcisi baba da ona biçilen hegemonik baba prototipini yeniden inşa eder. Kızını buyruklarıyla baskılayan, onu bir birey olarak görmeyen ve bu bağlamda kendi fikrini uygulayamayacağı direktifini veren bu baba prototipi; masalda babanın hegemonya alanını işaretler. Sonuç olarak hegemonik erkeklik, prens ve baba üzerinden tekrar bir temsiliyet kazanır.

Bir anti-masal örneği olarak Famide Uslu tarafından kaleme alınan ve dijital platformlarda yerini alan Kurbağa Prens masalı ise barındırdığı protaganistler ile farklı bir söylem oluşturur. Kral ve kraliçenin üç kızı vardır, bu kızlar kendi alanlarında oldukça yaratıcı ve başarılıdır. Ebeveynlerin yaşlanmasından dolayı ülke yönetimine geçen bu prensesler, diğer ülkelerle dayanışma ve yardımlaşma içindedir. Bir gün hikâye yazmak için ormanda vakit geçiren küçük prenses, çok sevdiği topunu kuyuya düşürür ve çıkarmak için çok çabalar. Tek başına topunu kuyudan çıkaramayan prensese, kuyudaki kurbağa yardım eder. Yardımı karşılığında ondan bir şey istemesini söyleyen prensese, kurbağa "Karşıllı olsun diye bana hediye vermene gerek yok. Bir şey dileseydim, sadece 
benimle arkadaş olmanı dilerdim" (Uslu 2020) ${ }^{85}$ cevabını verir. Prenses arkadaşlık kurmak adına karşılıklı emek verilmesi gerektiği düşüncesini kurbağa ile paylaşır ve prenses ile saraya gelmek isteyen kurbağaya "Seni götürürsem istediğini elde etmek için çaba harcamamış olacaksın. Bence arkadaşlık biraz da çaba ister. Bence bu çabaya değer. İstediğin zaman saraya gelebilirsin. Şimdilik hoşça kal." (Uslu 2020) der. Saraya tek başına gelebilerek prensese bu arkadaşlık için emek verebileceğini gösteren kurbağa ile prenses sonunda arkadaş olur. Bu arkadaşlık sayesinde insana dönüşen kurbağa; kayıp bir prenstir aslında ve kendi ülkesinin yönetiminde prensesten yardım alır. Her iki ülkenin de evrensel eşitliği kurabilme adınadayanışma içinde olduğu bir dünyanın inşasıyla yani masala yakışır mutlu bir sonla biter masal.

Geleneksel masalın aksine erkek ya da kadın protagonistinden herhangi birine efendi ya da köle rolü vermeyen bu anti-masal; dayanışma, özgürlük, emek, bireysel gelişim gibi temalarda okuyucuya örnek bir hikâye gösterir. Cinsiyeti ve cinsiyete yüklenen rolleri doğal bir yasa gibi dayatan hegemonya söyleminden ayrılan bu antimasal; cinsiyete yüklenen kalıpları altüst ederek kadına siyasi güç atfedebilirken, erkeğin kurtuluşunun cesaretli bir kadının yardımıyla olabileceğini de gösterir. Kadın ve erkeği birbirinin karşı cinsi olarak kodlamaz ve masal, geleneksel masalların aksine protagonistlerini evlilik üzerinden mutlu bir sona ulaşabilecekleri iletisini barındırmaz. Prensesin arkadaşlığını kazanması sonucu kurbağanın bir insana dönüştüğünü söyler; burada herhangi bir doğuştan atanan cinsiyet varlığını tekrar etmiyorken, insana dönüşen kurbağayı prens olarak tanımlamasından onun erkek olabileceği ihtimalini bırakır. Bu noktada masal, herhangi bir şekilde onun erkek ya da kadın oluşunu dile getirmez.

Geleneksel masalın prens üzerinden kurduğu hegemonik erkekliği tekrar etmeyen bu anti-masal örneği, anti-kahraman prensinde yaptığı yapısökümünü babada da tekrar eder. Babaya kızının kararlarına saygılı, evde hegemonik bir erkeklik kurma gayretinde olmayan ve bu bağlamda ne hegemonik erkeklik temsili ne de tabi kılınmış erkeklik temsili olmayan bir babalığın yeniden inşasını mümkün kılar. Nitekim bu anlamda Uslu'nun masalındaki hegemonik erkekliğin yıkımında yeniden inşa ettiği prototipleri birbirini destekler nitelikte olup anti-masalın hegemonik erkekliğin yıkımı amacına yakınlaştırır.

\section{Sonuç Yerine: Evde Oturanlara Prens, Evden Uzaklaşanlara Kurbağa?'}

Her ne kadar Connell'in erkeklik üzerine başlattığı tartışmaya pek çok farklı eleştirel yorumlar eklenmiş olsa da bugün Connell' in ortaya koymuş olduğu hegemonik erkeklik, erkeklerin kendi arasında kurmuş oldukları tahakküm ilişkisinin yanı sıra erkeklerin kadınlar üzerindeki otoritesini gösterirken aynı zamanda da bu tahakküm sisteminin değişebilirliğini görme adına da oldukça önemlidir. Bu kavramın doğurduğu tartışmalar neticesinde bugün tabi kılınmış erkeklik ile hegemonik erkeklik arasındaki hiyerarşi

\footnotetext{
${ }^{8}$ Masalın sayfaları e-book versiyonunda belirtilmemiştir.

${ }^{9}$ Prof. Dr. Hikmet Asutay’ın XV. Uluslararası Türk-Germanistik Kongresi’nde Kurbağa Prens masalı için yapmış olduğu yorumuyla.
} 
sistemini görebilme adına da yol açar.

[...] erkeklik, ziyadesiyle ilişkisel bir kavramdır: erkeklik, diğer erkeklerin önünde ve onlar için, kadınlığa karşıt olarak ve herşeyden önce kişinin kendi içindeki bir tür dişil korkusu içinde inşa edilmiştir. (Bourdieu 2018: 71)

Dişile duyulan bu korkuyu bastırma yolunda sözlü ya da yazılı olarak yıllardır eril hegemonyanın inşa ve temsili için erekselleştirilen masal, bugün otoriteyi yıkma adına yapısöküme uğrar. Yakışıklı olmasıyla fiziksel; prens olmasıyla da toplumsal güce sahip erkek prototipinin karşısına yerleştirilen erkeğin buyruğunu sorgulamadan kabul eden, baba -ya da diğer adlarıyla otorite gücü- tarafından uygulanan baskıyı kabul eden ve bu alanın dışına çıkmayan sadık kadın prototipiyle Kurbağa Prens geleneksel masalında; erkeğe hegemonik erkeklik yüklenirken kadın madunlaştırılır ${ }^{10}$. Geleneksel masallar, masalın değişmez yer-mekân-zaman belirsizliği yapısını iktidarın söylemini yeniden inşa etme alanı olarak kullanırken; anti-masallar ise bu yapıyı güvenli alan olarak işlevselleştirerek karşı bir söylem kurma adına kullanır. Böylece cinsiyet ya da toplumsal cinsiyet rollerini yeniden inşa eden gelenekseli yapı söküme uğratan anti-masal Kurbağa Prens ise doğuştan atanan cinsiyet varlığını sorgulamadan kadın ile erkek arasında dayanışmanın üretildiği, bireysel gelişimin desteklendiği ve cinsiyetten bağımsız eşit emek düşüncesinin vurgulandığı başka bir dünya gösterir. Bunu sadece ev-dışı bir alanda değil; geleneksellerin barındırdığı ev içerisi otoriter baba rolünü tekrar etmeyerek ev-içi alana da taşır.

Prens ya da baba prototipleriyle erkeğe belli normlar atayan ve böylece hegemonik erkekliği kuran geleneksel Kurbağa Prens masalında; fiziksel olarak güçlü, siyasi ya da ev içi otoriteye sahip, buyruğu dinlenen, kadını ve dolayısıyla da kendi otoritesine göre diğer erkekleri de kendi söylemine tabi eden bir erkeklik kurulmuştur. Kurbağa iken türcü bir yaklaşıma uğrayan ve dışlanan erkeği; bu hegemonik erkeklik kalıbına almasıyla onun varlığının onaylanacağı iletisini taşıyan masal, barındırdığı erkek ve kadın prototipler üzerinden bu doğuştan atanan cinsiyet temelli güç dengesi(zliği)ni inşa eder ve masalı mutlu bir evlilik sonuyla bitirmesiyle de bu sistemi meşrulaştırır. Bu masala muhalif bir duruş sergileyen Fadime Uslu'nun kaleminden çıkan Kurbağa Prens masalında ise; hegemonik erkeklik kurulumuyla karşılaşılmaz. Masal, kadın ve erkeğe yüklenen biyolojik farklılık söylemi üzerinden kurulan normları tekrar etmemekle birlikte; bireysel gelişimi, emeği, dayanışmayı, çoğulculuğu destekleyen bir kurgu inşa eder. Cinsiyetin ve dolayısıyla toplumsal cinsiyet kavramlarının dönüşüme uğradığı erkeklik çalışmaları sonucu farklı bir söylem kurabilme imkanını, dijitalleşmenin verdiği özgürlükçü alanın desteğiyle yazına geçiren anti-masallar; özellikle çocuklara başka bir dünya olasılığını görme fırsatı verirken yetişkinlerin kurduğu eril hegemonyanın yıkılması yolunda önemli araçlardır. Tür ya da cinsiyet ayrımı yapmayan, toplumsal cinsiyet rollerini pekiştirmeyen, güzellik ya da çirkinlik üzerinden değerler sistemi kurmayan, eril sistemin kadın kadar erkeği de kurbanlaştırdığı bilincinde masallar üretmek; heteronormatif

10 İlk defa Antonio Gramsci tarafindan alanyazınına taşınan madun kavramı, genel tanımıyla altta bulunun,kullanılan ve hegemonya karşısında baskın bir yapı barındırmayan gruplar. Gayatri Spivak'ın feminist okumadan geçirdiği ilgili kavram; duyulamayan, kendine ait dili olmayan ötekiliğin bir temsilidir. 
ataerkilliği kendi araçları üzerinden altüst etmek adına önemli bir yapısökümcü eylemdir ve bu eylemlerin çoğalmasının yanı sıra desteklenmesinin gerekliliğini ortaya koyan bu karşılaştırma; masalların işlevini yeniden görülür kılar.

\section{Kaynakça}

Bourdieu, Pierre (2018): Eril Tahakküm. İstanbul: Bağlam Yayınları.

Butler, Judith (2016): Cinsiyet Belast: Feminizm ve Kimliğin Altüst Edilmesi. İstanbul: Metis Yayınları.

Connell, Raewyn (2000): Toplumsal Cinsiyet ve İktidar. İstanbul: Ayrıntı Yayınları.

Foucault, Michel (2016): Cinselliğin Tarihi. İstanbul: Ayrıntı Yayınları.

Grimm Kardeşler (2017): Grimm Masalları. İstanbul: Can Sanat Yayınları.

Köse, Hüseyin (2015): Skolastik Fantazya: Hayalden Endüstriye Popüler Kültür Odağında Masal Çözümlemeleri. İstanbul: Ayrıntı Yayınları.

Lacan, Jacques (2013): Psikanalizin Dört Temel Kavramı. İstanbul: Metis Yayınları.

Propp, Vladimir (1985): Masalın Biçimbilimi. İstanbul: Bilim/ Felsefe/ Sanat Yayınları.

Sancar, Serpil (2016): Erkeklik: İmkansız İktidar. Ailede, Piyasada ve Sokakta Erkekler. İstanbul: Metis Yayınları.

Sezer, Melek Özlem (2018): Masallar ve Toplumsal Cinsiyet. İstanbul: Kor Kitap.

Uslu, Fadime (2020): Kurbağa Prens: Bir Grimm Kardeşler Masalı. İstanbul: Can Sanat Yayınları. 